Espacio, Tiempo y Forma, Serie II, Historia Antigua, t. 23, 2010, págs. 497-518

\title{
Zeus/Júpiter y Antiope en los Mosaicos Romanos
}

\author{
Zeus/lupites and Antiope in the Roman Mosaics
}

M. PILAR SAN NICOLÁS PEDRAZ*

\begin{abstract}
RESUMEN ABSTRACT
Se realiza un estudio de los mosaicos romanos con la representación del mito de

Zeus/Júpiter y Antiope en sus distintas versiones narradas por las fuentes literarias, abordando su contexto arqueológico y cronológico.

In this paper we are going to examine the Roman mosaics with the representation of the myth of Zeus/Jupiter and Antiope in the various versions told by the literary sources, tackling both their archeological and chronological context.
\end{abstract}

PALABRAS CLAVE:

Zeus, Jupites, Antiope, Mosaicos romanos

KEYWORDS:

Zeus, lupiter, Antiope, Roman mosaics

Dentro de la musivaria romana existe un conjunto no muy numeroso pero destacado y relativamente variado del mito de los amores de Zeus y Antiope, que tiene gran interés por sus peculiares iconografías de las distintas versiones narradas por las fuentes escritas grecorromanas ${ }^{1}$. En este trabajo analizaremos las

* UNED (España). E-mail: psam@geo.uned.es

1 Según Pausanias (II 6, 2-3; IX 17, 3-4; X 32,6) Antiope fue hija del tebano Nicteo y no del dios-río Asopo. En Homero (Od. XI 260) es hija de Asopo, sin embargo para Schol. Ap. (Rh. I 735) serían dos Antiopes distintas. Zeus se unió a ella en figura de un sátiro, concibiendo dos gemelos, Anfíon y Zeto, los Dióscuros tebanos (Ovid. Met. VI 108; L. Plácido narrat. fabul. VI 1; Schol. Ap. Rh. IV 1090; Non. Dyon. $X X X I$ 218). Antes de dar a luz y tras las amenazas de su padre, Antíope huye a la corte de Epopeo, rey de Sición, con quien se casa (Apol. Bibl. III 5, 5) o fue raptada por éste, entonces Nicteo emprende una batalla en donde ambos quedan heridos, muriendo primero Nicteo y luego Epopeo, y su sucesor Lamedonte entrega Antíope a Lico (Pausanias II 6, 1-4). Aunque en la versión de Apolodoro Nicteo, desesperado por la fuga de Antiope, se suicida, pero antes le encarga a su hermano Lico que le vengue. Lico emprende una breve campaña contra Sición, en la cual mata a Epopeo y se lleva a Antíope prisionera a 
variantes del mito en los mosaicos hallados en las diferentes áreas geográficas y culturales del Imperio romano. Igualmente abordaremos los diferentes contextos arqueológicos, cronología y el contenido simbólico de estas representaciones, que no solo son una simple aventura amorosa, descrita en la mitología greco-romana y en los textos literarios, sino que sobre todo constituyen una alegoría de fecundidad y riqueza a través de la hierogamia de la pareja.

En las escenas representadas en los mosaicos romanos se aprecian varios episodios o secuencias del mito: la primera fase de la leyenda con la seducción de Zeus/Júpiter, que a su vez se puede dividir en dos momentos, uno con la sorpresa o acoso, y otro con la seducción y aceptación, además de una segunda fase o etapa final con la consecuencia de la unión de la pareja y su desenlace.

El primer episodio de la leyenda, que relata el encuentro por sorpresa de ambos personajes y el acoso de Zeus/Júpiter a Antiope, está representado en cinco mosaicos que siguen una secuencia iconográfica. En un panel del mosaico de Fernán Nuñez (Córdoba), del siglo III², con los Amores de Zeus/Júpiter ((Fig. 1), que se deshizo al ser levantado, sólo se conserva de esta escena un eros con carcaj a la espalda y el haz de rayos en la mano, personificación de la atracción amorosa del dios (Fig. 2); no obstante se sabe por las descripciones de los excavadores que en la escena Antiope huía del lecho cuando el sátiro intentaba seducirla por lo que puede decirse que esta representación probablemente sería la primera secuencia del grupo.

En los otros cuatro mosaicos, aunque Antiope no está en el lecho, se documenta igualmente el momento mismo del acoso. En el pavimento de los Amores de Zeus/Júpiter de Itálica, del siglo II ${ }^{3}$ (Fig. 3), el sátiro persigue a Antiope que acaba

\footnotetext{
Tebas. Durante el camino, en el Citerón, monte beocio fronterizo con la Megárida y el Atica, Antiope da a luz a los hijos de Zeus, que fueron abandonados en el lugar y recogidos por un pastor. Zeto se ocupará del ganado y Anfíon tocará admirablemente la lira enseñado por Hermes (Apol. III 5, 5; Paus. IX 5, 7-8; Hor. epist. I 18, 41-44). En Tebas, Antíope fué atormentada y encadenada por Lico y su segunda esposa Dirce, celosa de su belleza. Un día las cadenas se desataron por si solas y Antiope huye de la ciudad en busca de sus hijos, pero estos no la reconocieron y la entregaron, otra vez, a Dirce que había ido a buscarla. Sin embargo el pastor que había recogido a los gemelos les reveló que Antiope era su madre, acudieron a liberarla y vengaron el maltrato al que había sido sometida por Lico y Dirce. A está la castigaron atándola viva a un toro, que la arrastró y desgarró por las rocas, siendo después su cuerpo arrojado por los dos hermanos a una fuente próxima a Tebas que, desde entonces, tomó el nombre de Dirce, según señalan Pausanias (II 6s.; IX 17, 3s.; X 32, 6) y Apolodoro (Bibl. III 5, 5). Pero Dionisos, enojado por la muerte de Dirce, volvió loca a Antíope quien anduvo errante por todo Grecia hasta que el corintio Foco, rey de la Fócide y descendiente del astuto Sísifo, la curó y se casó con ella, mientras que los gemelos, Anfion y Zeto, tomaron Tebas y reinaron en lugar de Lico. La relación entre Dirce y Dionisos aparece mencionada en las Bacantes de Euripides (Bacch.519-535) en la que ya se alude a la conexión entre la infancia de Dionisos y la fuente Dirce, y en las Dionisiacas de Nonnos (Dyon. 46, 139-142) que aparecía en el argumento central de la obra de Antiope de Euripides que no se ha conservado.

2 D. FERNÁNDEZ GALIANO, Nuevas interpretaciones iconográficas sobre mosaicos hispanorromanos, Museos 1, 1982, p. 17-27.

${ }^{3}$ A. BLANCO FREIJEIRO, Mosaicos romanos de Itálica, Corpus de Mosaicos romanos de España III, Madrid 1978, p. 25-26, n. 1, láms. 1-7. M. DURAN PENEDO, Dirce y Antiope: dos imágenes de valores contrapuestos del ciclo tebano, L Africa Romana XVII, 2008, p. 1313, nota 46, p. 1315; ID., Las preferencias iconográficas de los clientes refinados hispano-romanos, al encargar los mosaicos de sus viviendas, Monte Catano 9, 2008, p. 14, nota 68.
} 


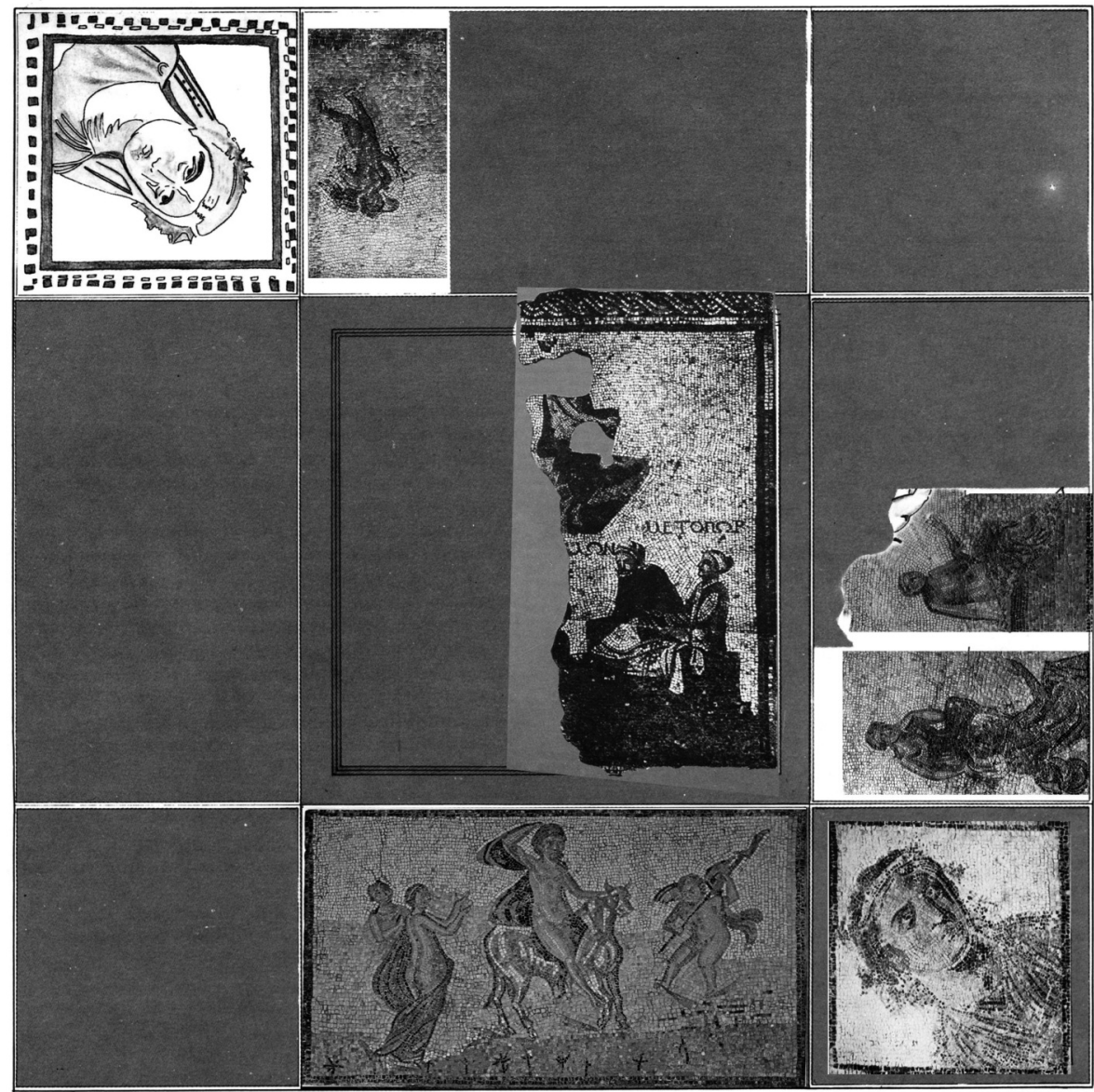

Fig. 1. Mosaico de Córdoba (España). Siglo III.

de caer de rodillas al ser alcanzada por éste4; la doncella está vista de espaldas al espectador, señalando aún más el rechazo al dios, tipo que a su vez se da en la iconografía de los Amores de Zeus/Júpiter con Europa ${ }^{5}$ y Leda ${ }^{6}$, de Amymone ${ }^{7}$, Al-

${ }^{4}$ Esta iconografía de la joven de rodillas aparece ya en un relieve ateniense de mediados del siglo II a.C., conservado en el Museo Nacional de Atenas cf. LIMC, I Antiope I, no 2.

5 G. LÓPEZ MONTEAGUDO y M.P. SAN NICOLÁS PEDRAZ, El mito de Europa en los mosaicos hispano-romanos, Análisis iconografico e interpretativo, Espacio, Tiempo y Forma, II, 18, 1995, pp. 389-399.

6 M.P. SAN NICOLÁS PEDRAZ, Leda y el cisne en la musivaria romana», Espacio, Tiempo y Forma, I, 12, 1999, p. 368-372, fig. 17 (mosaico de Kouklia, Palaepaphos, Chipre), fig. 18 (Suasa, Italia), fig. 19 (Écija, España); M.P. SAN NICOLÁS PEDRAZ, Sobre una particular iconografía de Leda en el mosaico hispano de Écija. IXème Colloque Internactional pour I étude de la Mosaïque antique et medievales (Roma 2001), Paris 2005, vol. 2, 975-985.

7 J.P. DARMON, Nympharum Domus. Les pavements de la Maison des Nymphes à Neapolis (Nabeul, Tunisie) et leur lecture, Leiden, 1980, pp. 104-109, lám. LIV. 


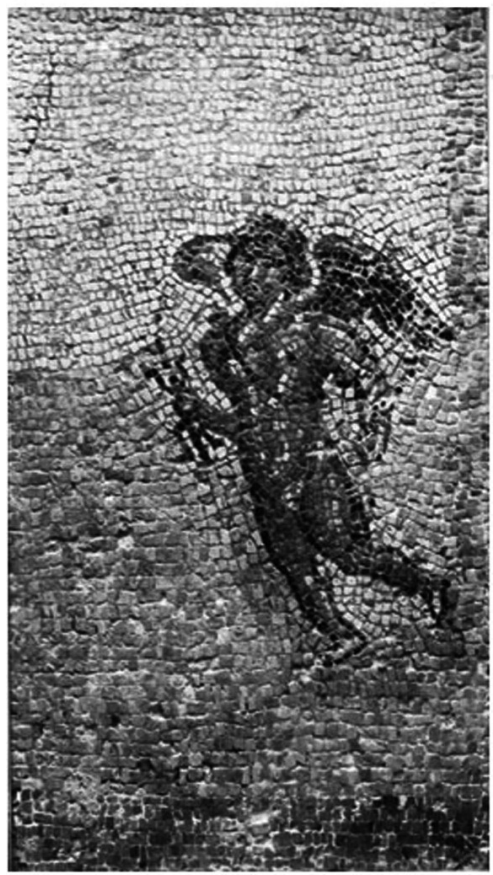

Fig. 2. Detalle del mosaico de Córdoba.

feo y Aretusa ${ }^{8}$, Hylas y las ninfas ${ }^{9}$, o de ménades/ninfas y sátiros ${ }^{10}$, pudiendo estar inspirados en una pintura de Apeles que se distinguía por « la gracia» de su arte y por sus « personajes vistos de espaldas» (Plin., NH, 35,79). Igualmente el pavimento del cubiculum de la Sollertiana Domus de El Djem, fechado a principios del siglo III y enmarcado también en el contexto de los Amores de Zeus/Júpiter ${ }^{11}$, tiene la misma iconografía que el mosaico hispano, con Antiope vista de espaldas protegiéndose del sátiro, aunque aquí rechaza con la mano a su agresor (Fig. 4).

8 I. MAÑAS ROMERO, Representaciones culturales de la violencia de género: acoso, rebeldia y sumisión en el mosaico romano. En M. L. Neira (cord. y ed.), Representaciones de mujeres en los mosaicos romanos y su impacto en el imaginario de estereotipos femeninos, CVC, Madrid 2011, p 70, lám 37.

9 I. MAÑAS ROMERO, El mosaico italicense de Hylas, Romula 3, 2004, 109-110, figs. 4 y 5

10 K.O.M. DUNBABIN, The Mosaics of Roman North Africa. Studies in Iconography and Patronage, Oxford, 1978, p. 258, nº 18A (EI Djem, finales del siglo II), 270, no 25B, lám. LXVIII, fig. 173 (Sousse, siglo III).

11 L. FOUCHER, Découvertes archéologiques à Thysdrus en 1960, Tunisie 1962, p. 15-25, láms. XV-XX ; C. DULIERE y H. SLIM, Thysdrus El Jem, en M. Alexander y M. Ennaifer, Corpus des Mosaïques de Tunisie, Túnez 1996, vol. III, p. 27, láms. XIV, LXV,7A. 


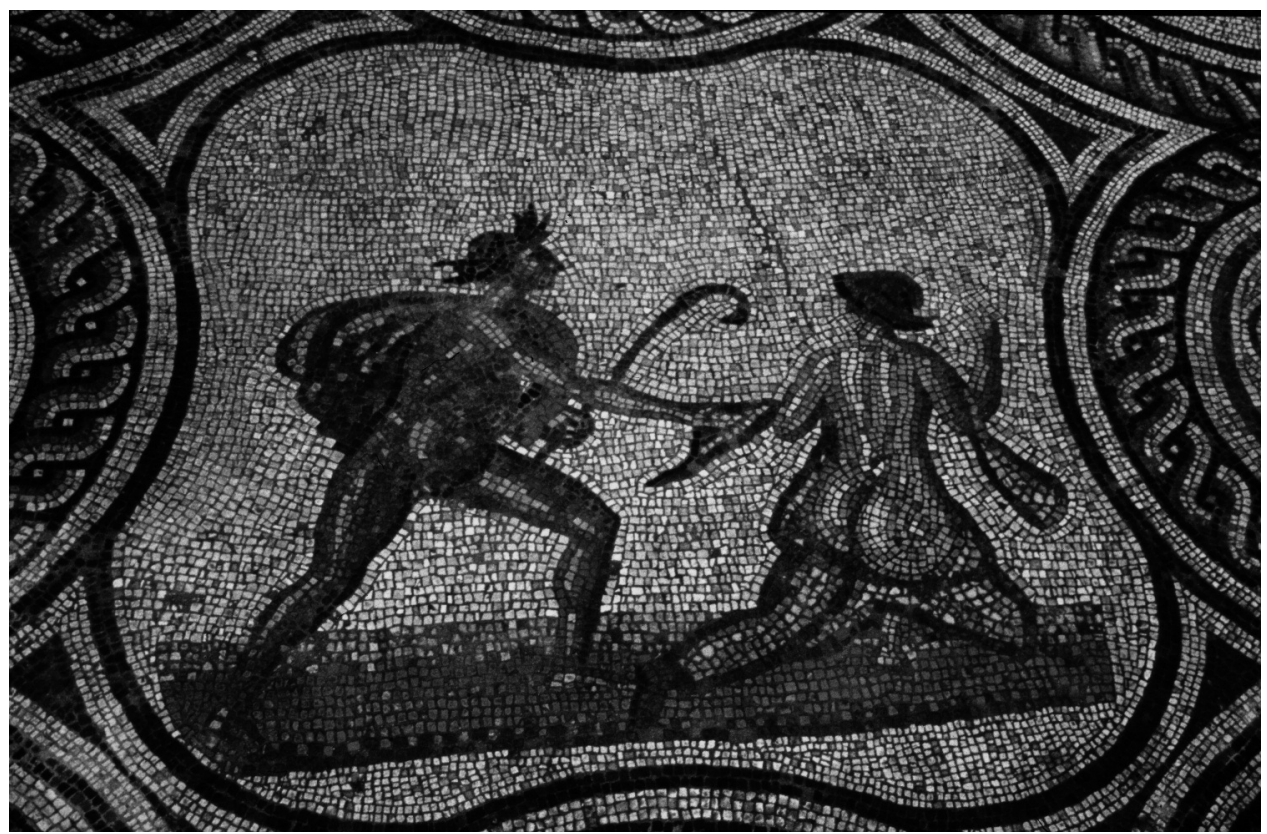

Fig. 3. Mosaico de Itálica (España). Siglo II.

Los personajes del mosaico argelino del caldarium de las Termas de los Fhiladelphi en Timgad, que se fecha a comienzos del siglo III, se han identificado como Zeus/Júpiter y Antiope ${ }^{12}$, y, aunque presenta la misma iconografía que los dos ejemplares anteriores, se aprecia la galantería del sátiro que intenta sujetarla por detrás evitando su huida (Fig. 5). Esta composición muestra un gran paralelismo con la del mosaico de Antakya, procedente de la Casa del barco de Psique, fechado en el siglo $\mathrm{VI}^{13}$, aquí la joven intenta levantarse, a juzgar por el tympanon que lleva en su mano derecha, y se aleja de él, mientras su rostro se vuelve para mirar a su agresor (Fig. 6). Las escenas de estos dos mosaicos representan el momento inmediatamente posterior a los mosaicos italicense y de El Djem, en los que la joven está representada de espaldas al espectador.

12 S. GERMAIN, Les mosaïques de Timgad, Paris 1969, p. 77-79, no 96, láms. XXXIII-XXXIV; K.M.D. DUNBABIN, op. cit. en nota 10, p. 275 , n. 9

13 El mosaico de Antakya ha sido interpretado como Apolo y Dafne, D. LEVI, Antioch Mosaic Pavements, Princeton 1947, p. 182-183, lám. C; LIM III, Daphne, no 22. Ambos personajes llevan coronas vegetales similares a los mosaicos de Málaga y Zeugma, que posteriormente veremos. 


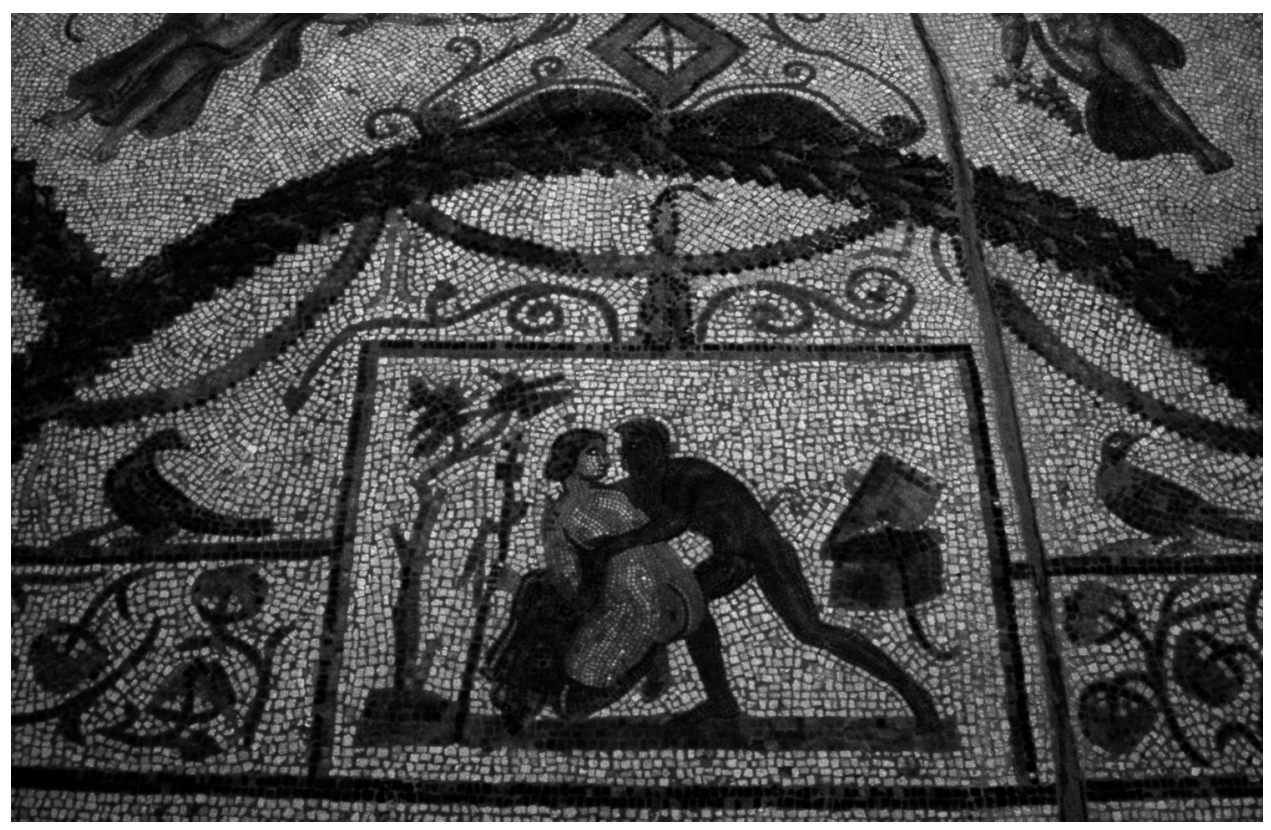

Fig. 4. Mosaico de El Djem (Túnez). Principios del siglo III.

En estos cuatro mosaicos se sigue la iconografía tradicional de « la ninfa sorprendida» que fue utilizada multitud de veces en el arte helenístico y romano para representar las persecuciones o seducciones eróticas, por lo que la mayoría de las veces la identificación del grupo puede ser hipotética si no hay inscripciones o elementos iconográficos claros. El esquema ha sido utilizado indistintamente para representar, además de ninfas o ménades perseguidas por sátiros ${ }^{14}$, a varios grupos como Apolo y Dafne, Apolo y Cirene ${ }^{15}$, Neptuno y Amymone ${ }^{16} \mathrm{o}$ al propio Zeus/Júpiter y Antiope como hemos visto.

Otras escenas musivas documentan este episodio de Antiope y Zeus metamorfoseado en sátiro pero con la variante de la persuasión y aceptación de ambos personajes, siguiendo las versiones de los autores antiguos: la seducción del dios para cumplir su deseo y el enamoramiento de la joven que no se resiste, ni se aleja, sino que activamente, como una ménade/ninfa, le sigue eró-

14 A. BEN ABED BEN KHADER, L edifice du Satyre et de la Nymphe de Pupput, VI Coloquio Internacional sobre MosaicoAntiguo (1990), Madrid 1994, p. 239-251 (mosaico de Pupput, Antigua Hammamet, de fines del siglo IV o comienzos del V).

15 S. STUCCHI, p. 23-28; G. LÓPEZ MONTEAGUDO, Representaciones de la ninfa Cirene en los mosaicos romanos, en L. Gasperini-S.M. Marengo, Cirene e la Cirenaica nell Antichità. Atti del Convegno Internazionale di Studi (Roma 1996), Roma 2007, pp. 355-375.

16 J.P. DARMON, op. cit. en nota 7. 


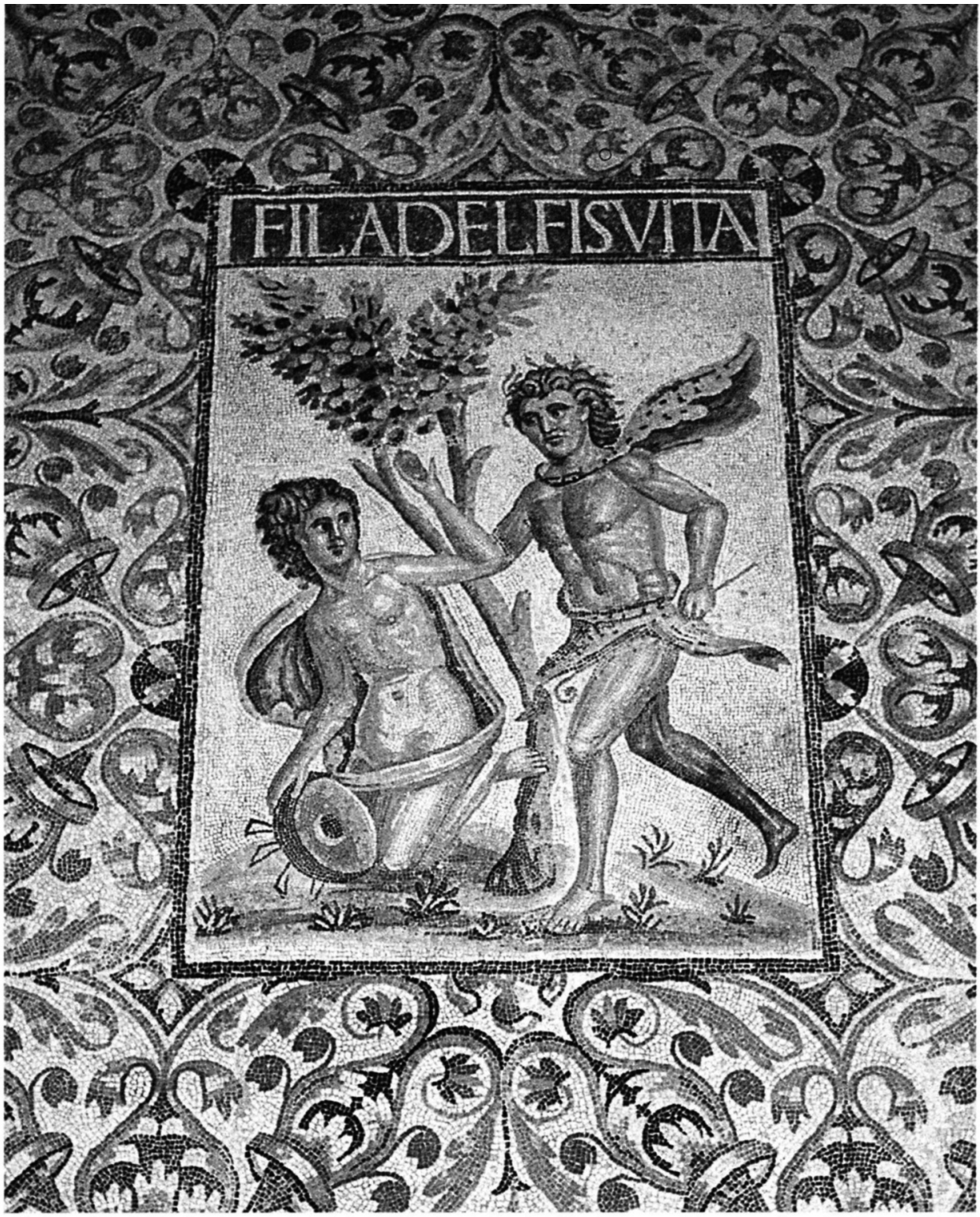

Fig. 5. Mosaico de Timgad ( Túnez). Principios del siglo III.

ticamente en su danza, como preludio de la danza nupcial y semejante a la danza dionisiaca:

Has oído hablar del embaucador juego amoroso del que fue víctima Antiope, del sátiro riente, de la artimaña de un amante engañoso...Zeus el que gobierna en 


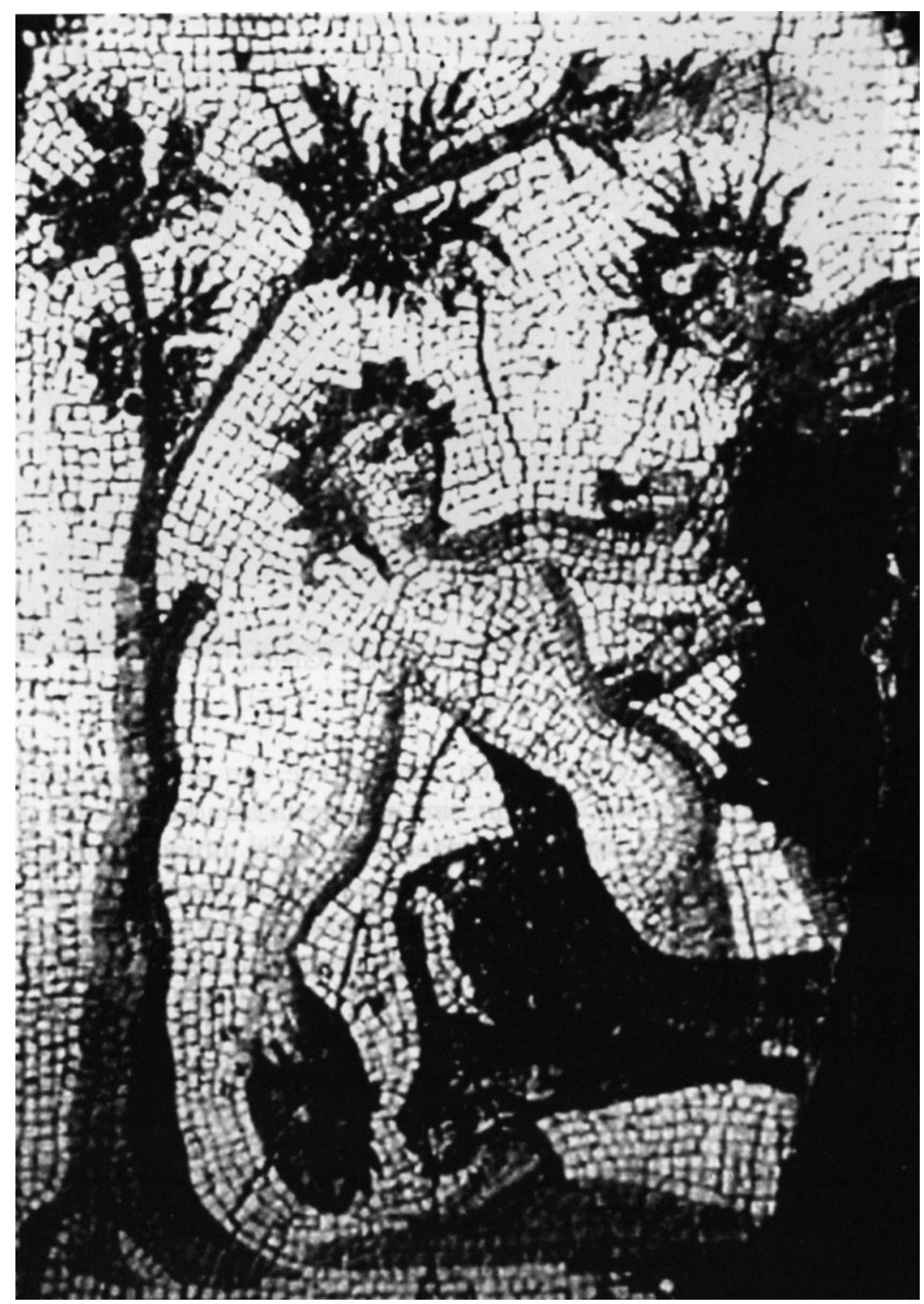

Fig. 6. Mosaico de Antakya (Turquía). Siglo VI.

las alturas, tomó una vez la forma de un sátiro, y sedujo a la doncella Antiope bajo una falsa apariencia, con el cortejo engañoso de una danza nupcial (Nonnos, Dyon. XVI, 240; XXXIII, 301).

Este momento del mito, en donde se inicia el preludio del proceso amoroso, se encuentra, aunque con algunas variantes, en un mosaico de Devnya (Bulgaria), en 
dos pavimentos de Zeugma, (Turquía), fechados a finales del siglo Il-mediados del III que fueron hallados en la Casa de Poseidón, en un mosaico en Málaga (España) y en otro de Beyrouth (Líbano). La mayoría fueron hallados en cubicula ${ }^{17}$ y los personajes están identificados con sus nombres.

En el mosaico de Marcianopolis, Devnya (Bulgaria), del siglo IV, descubierto en la Casa de Antiope ${ }^{18}$ en un cubiculum- vestidor, ambos personajes aparecen en uno de los pentágonos inscritos en un cuadrado, tocados con coronas vegetales, en pie, vistos de medio lado y representados completamente desnudos. El sátiro detrás de la doncella la agarra, mientras ella sutilmente gira su cabeza hacía atrás para mirarle coqueteando. En los laterales se encuentran sus nombres en griego CATIPOC/ ANTIOPH. (Fig. 7) ${ }^{19}$. Esta escena parece corresponder al momento anterior a la danza, y por lo tanto sería el primer ejemplar de la serie.

El pavimento de Zeugma, Belkys, Gaziantep (Turquía), hallado en un pequeño cubiculum, $\mathrm{P} 23^{20}$, está compuesto por dos paneles, en el de abajo se representa a la nereida Galatea con su nombre (GALATIA) montada sobre una pantera. En el superior se ha figurado, en primer plano, a dos personajes en pie, vistos de frente, con las cabezas giradas, con coronas vegetales como en el pavimento de Antakya (supra), y mirándose, estableciéndose claramente un contacto visual que indica un momento clave en el encuentro erótico: el enamoramiento recíproco que se expresa en la mirada. El sátiro a la derecha, va desnudo, solamente lleva la pardalis sobre el brazo izquierdo y sostiene, en la mano el característico pedum; con la otra mano galantemente coge el brazo izquierdo de Antiope. Ésta cubre su desnudez con un manto que cae por la espalda y que recoge con el brazo, envolviendo las piernas, levantando su brazo derecho portando el tympanon. Les acompaña la inscripción griega $A N T I O(P) H /$ CATYPOC (Fig. 8).

El mosaico de Málaga, siglo III, fue descubierto en la villa de Torre de Benagalgón y pavimentaba la habitación $n^{\circ}$ 1 de la pars urbana considerada como

17 Estos espacios de carácter reservado no solo están destinados al reposo o a los placeres conyugales y extramatrimoniales sino a otros menesteres como la lectura, conversaciones con huéspedes, negocio o política, cf. P. URIBE AGUDO, Los espacios reservados (cubicula) en las viviendas romanas urbanas del cuadrante nordeste de la Península Ibérica, Saldvie 7, 2007, pp. 93-110 (con bibliografía).

18 A. MINCHEV, The Roman and Late Roman City, Conference veliki Turnovo (2000), 2002, p. 250 251, lám. 7; LIMC Antiope I, Suppl. 2009, p. 68.

${ }_{19}$ Es frecuente la utilización de epígrafes musivos en griego en la parte oriental del Imperio, en particular los nombres de los personajes mitológicos, como reflejo de la tradición helénica, cf. J. BERMEJO TIRADO, La construcción de una identidad pagana: los mosaicos de tema mitológico como documento para una historia cultural en Antioquía, en Maㅡ Luz NEIRA (ed.) Mitología e Historia en los mosaicos romanos, Ediciones JC, Madrid 2010, pp. 80-82.

20 M. ÖNAL, Mosaics of Zeugma, Estambul 2002, p. 42-43; J.P. DARMON, Le programme idéologique de la maison de la Téleté dionysiaque, dite de Poseidón á Zeugma (Belkiis, Turquie), CMGR IX, 2 , Roma 2005, p. 1285-1286, lám. 6. 


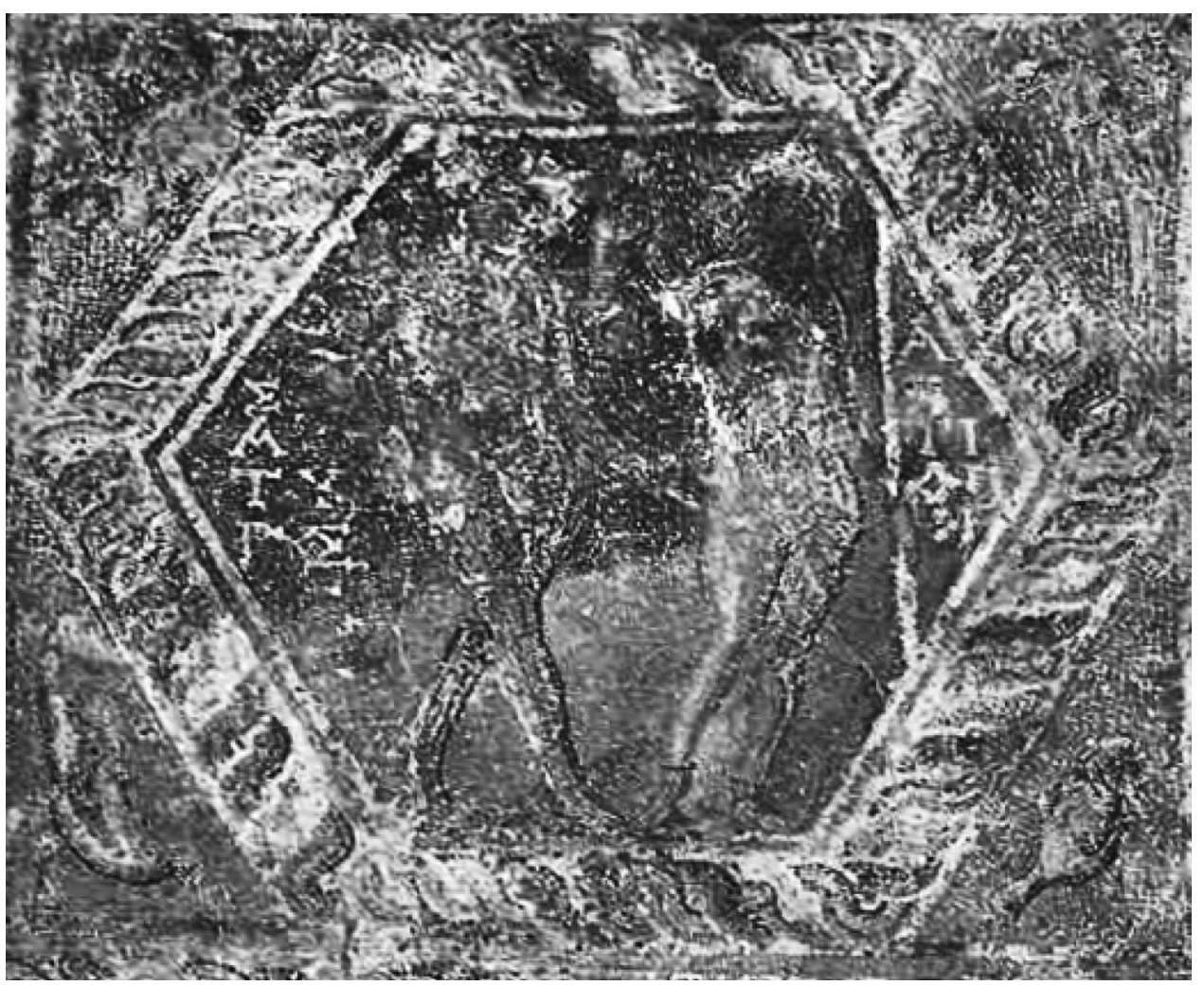

Fig. 7. Mosaico de Devya (Bulgaria). Siglo IV.

cubiculum ${ }^{21}$. En el medallón central se representa a ambos personajes, con coronas vegetales, como el mosaico anterior de Zeugma, bailando, con las cabezas giradas, mirándose frente a frente, expresando su mutua atracción amorosa. El sátiro, completamente desnudo agarra firmemente con su mano derecha

21 P. RODRIGUEZ OLIVA, Nuevos mosaicos romanos de la provincia de Málaga, Anuario de la Real Academia de Bellas Artes de San Telmo 6, 2006, p. 21-33; I. MAÑAS, S. VARGAS, Nuevos mosaicos hallados en Málaga: las villas de la Estación y de la Torre de Benagalbón, Mainake 29, 2007, p. 315-338.; P. RODRIGUEZ OLIVA, J. BELTRÁN FORTES, Villae romanas de la costa malacitana frontera al África. Las villae de Torrox-costa y de la Torre de Benagalgón, L Africa romana XVII (2006), Roma 2008, p. 1280-1288; ID., Arqueología de las villae romanas de la costa malacitana, Habis 39, 2008, p. 230-232. El campo del mosaico, muy deteriorado, presenta dos calles laterales decoradas con peltas adosadas, alternativamente horizontales y verticales, con ejemplares en Acholla (Túnez) e Itálica, y un emblema central cuadrado en el que se inscriben un cuadrado sobre la punta y un círculo o medallón M.P. M.P. SAN NICOLÁS PEDRAZ, On Mosaic from Málaga with the depiction of Zeus/Jupiter and Antiope, La Mosaïque Gréco-Romaine IX, Bursa, Turquía (en prensa). 


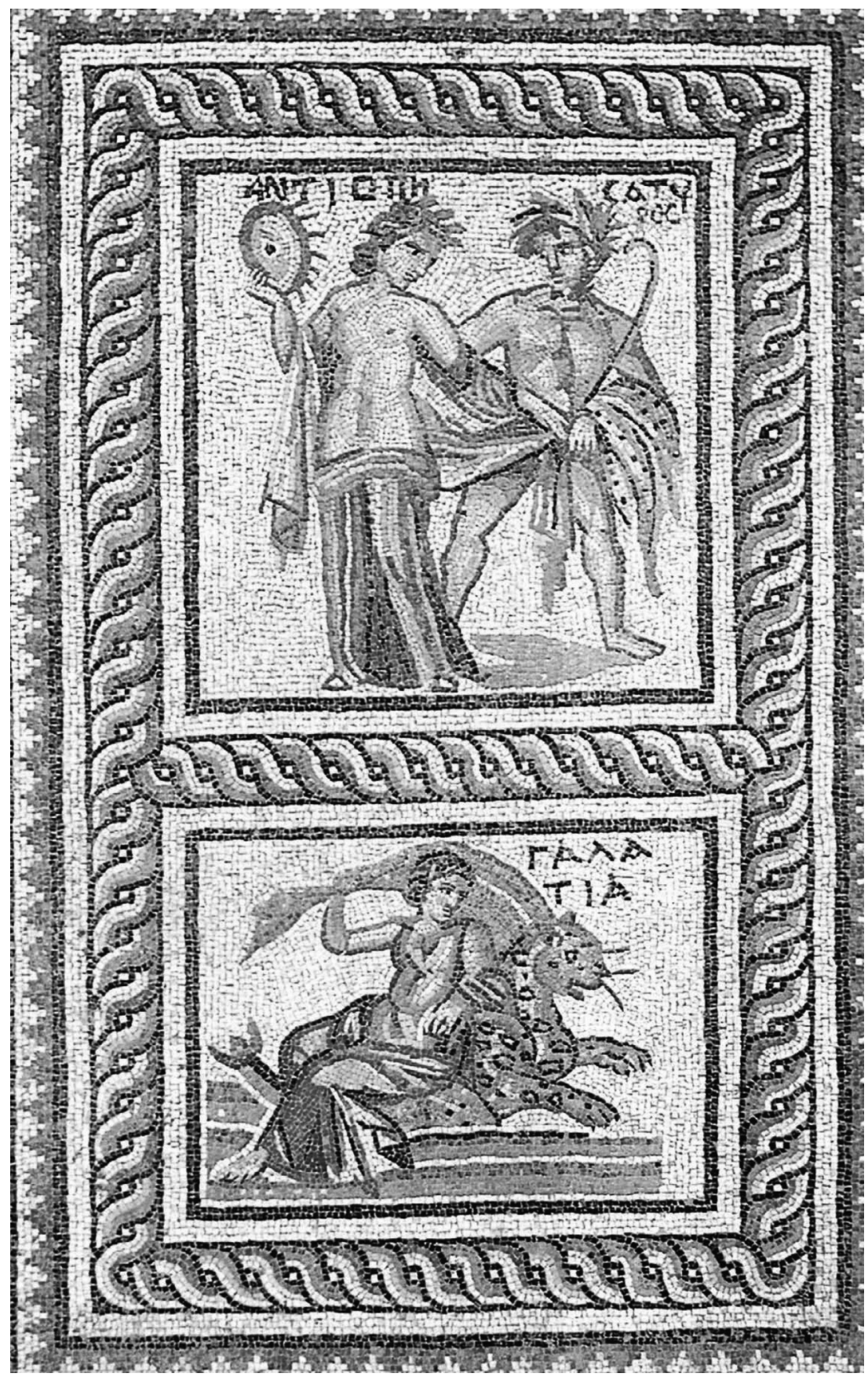

Fig. 8. Mosaico de Zeugma (Turquía). Finales del siglo II-mediados del III. 
el brazo izquierdo de la doncella, atrayéndola hacía sí, mientras ella de espaldas al espectador lo acepta gustosa y cubre sus piernas con un manto, dejando al descubierto su cuerpo; el gesto levantado de su mano derecha portando el tympanon, indica, al igual que sus pies, que sigue el movimiento de la danza. Aunque el sátiro no lleva el característico pedum ni viste pardalis, la identificación del grupo está fuera de toda duda por su inscripción en latín: SATYR/ ANTIOPA (Fig. 9).

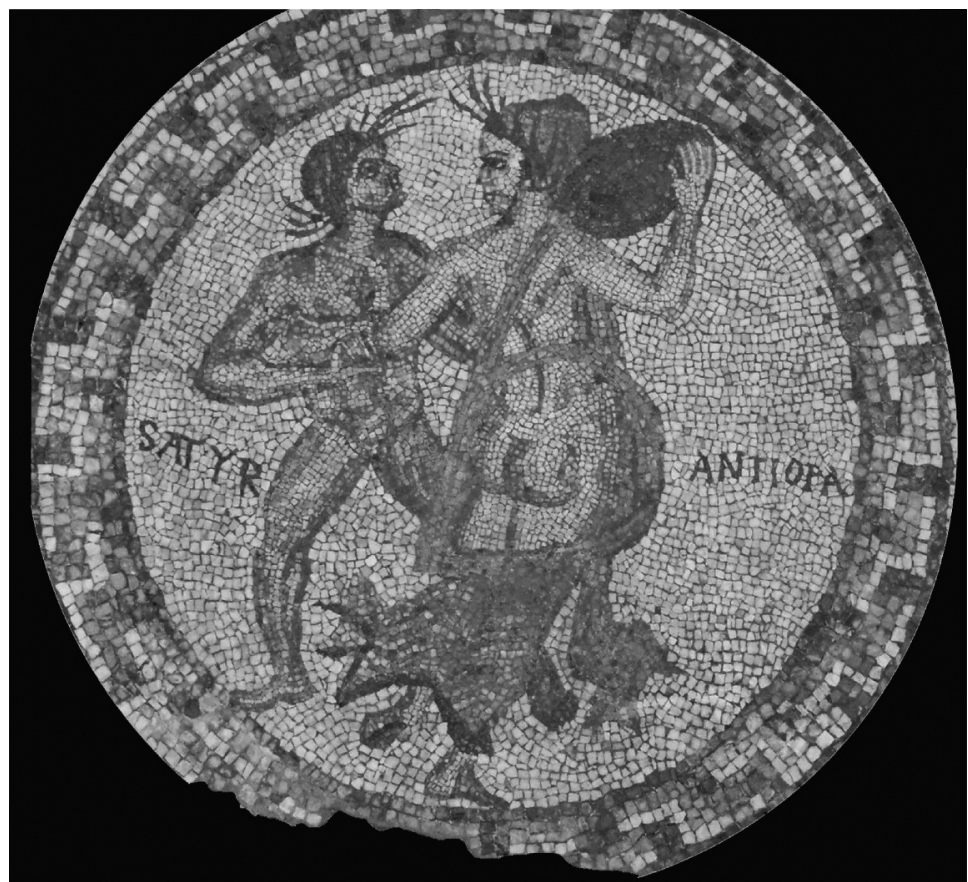

Fig. 9. Mosaico de Málaga (España). Siglo III.

Paralelos muy próximos a la iconografía del mosaico malagueño se encuentran en los mosaicos dionisiacos, también del siglo III, de la antigua Sousse (Túnez) ${ }^{22}$ y de Köln (Alemania) ${ }^{23}$, en los que se percibe uno de los esquemas tipo para figurar seducciones o persecuciones idílico-eróticas del repertorio helenístico y romano, los personajes están bailando, la ménade se encuentra de espaldas, mientras que el sátiro la seduce, portando también en los dos últimos ejemplares el tympanon.

El segundo pavimento turco fue localizado en el cubiculum P38 (A14) ${ }^{24}$, una de las habitaciones más alejadas del extremo sur del ala central. El emblema en dos de sus lados está rodeado por un marco de rectángulos, dentro de los cuales se han re-

\footnotetext{
22 K.M.D. DUNBABIN, op. cit., en nota 10, p. 270, no 25B, lám. LXVIII, fig.173.

23 K. PARLASKA, Die Römischen Mosaiken in Deutschland, Berlin 1959, p. 77. lám. 66.72

24 J.P. DARMON, op. cit. en nota 20, p.1291-1293, lám. 12.
} 
presentado diversas aves. El grupo, girado al espectador, aparece en movimiento, como bailando o emprendiendo el momento inicial del proceso amoroso, también con indicación de los nombres en griego de los personajes CATYPOC/ANTIOPH. El sátiro con corona vegetal y situado a la izquierda como en los mosaicos anteriores, agarra con su mano derecha el brazo derecho de la joven, mientras que con la izquierda intenta despojarla de la vestimenta. Ella, que parece alejarse de él, inicia, con sutil resistencia, un gesto de huída, levantando la mano izquierda, mientras su rostro se vuelve ligeramente a mirar a su agresor, actitud que forma parte del juego erótico; al igual que en los ejemplares anteriores las piernas están cubiertas con el manto, que cae por la espalda y recoge con su brazo izquierdo (Fig. 10).

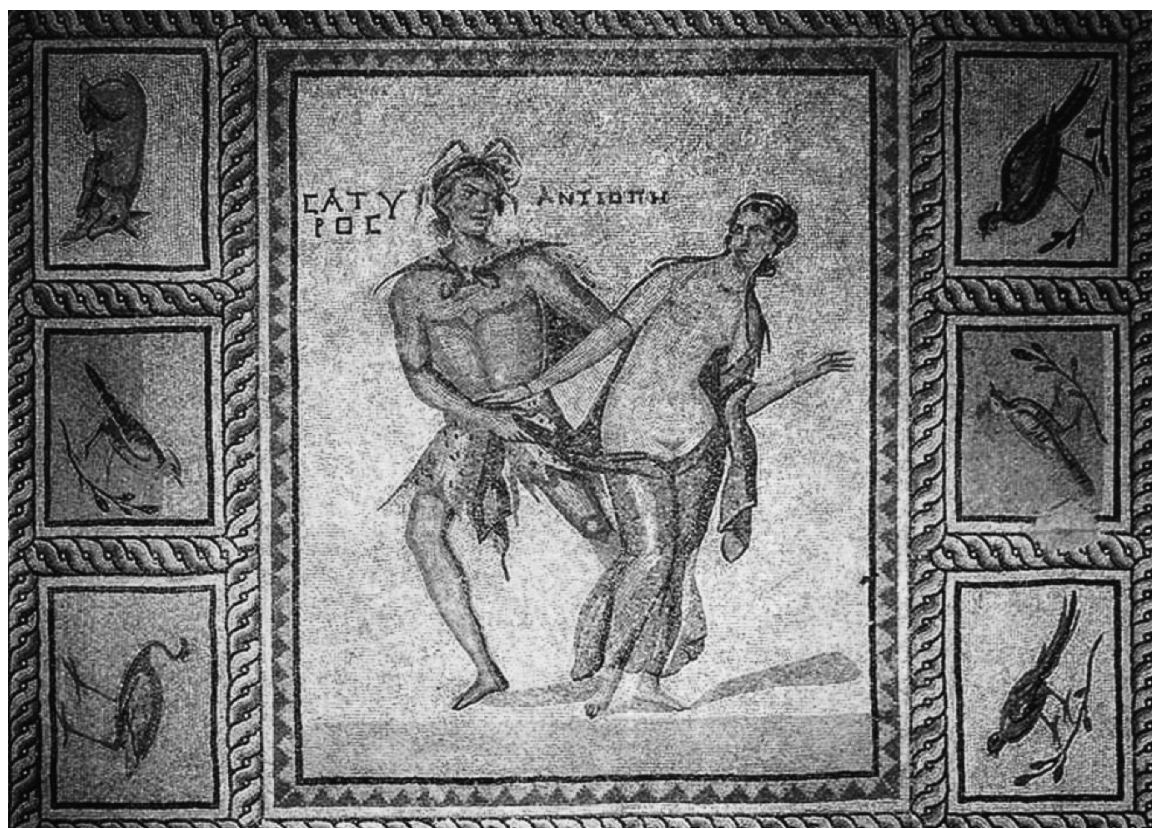

Fig. 10. Mosaico de Zeugma (Turquía). Finales del siglo II-mediados del III.

En el mosaico de los Amores de Zeus/Júpiter de Beyrouth (Libano), fechado en el siglo IV ${ }^{25}$, Antiope aparece de pie seguida del sátiro con pardalis sobre el hombro izquierdo, posando su mano derecha en la espalda de ella, intentando quitarle el manto. La joven con la mano derecha retiene sutilmente su vestimenta y levanta el brazo derecho, como en los mosaicos de Benagalbón y de Zeugma, pero aquí sujetando con la mano una syrinx y carece de inscripción que identifique a los personajes (Fig. 11).

${ }_{25}$ M. CHEHAB, Mosaïque du Liban, BullMusBeyrouth, 14-15, 1958-1959, p. 21-27 ; O. WATTEL-DE CROIZANT, Les " amours des dieux» sur les mosaïques du Mussée National de Beyrouth, Actes du VIIleme. Colloque Internationale de la Mosaïque Antique , (Lausana 1997), 2001, II, p. 265-275. 


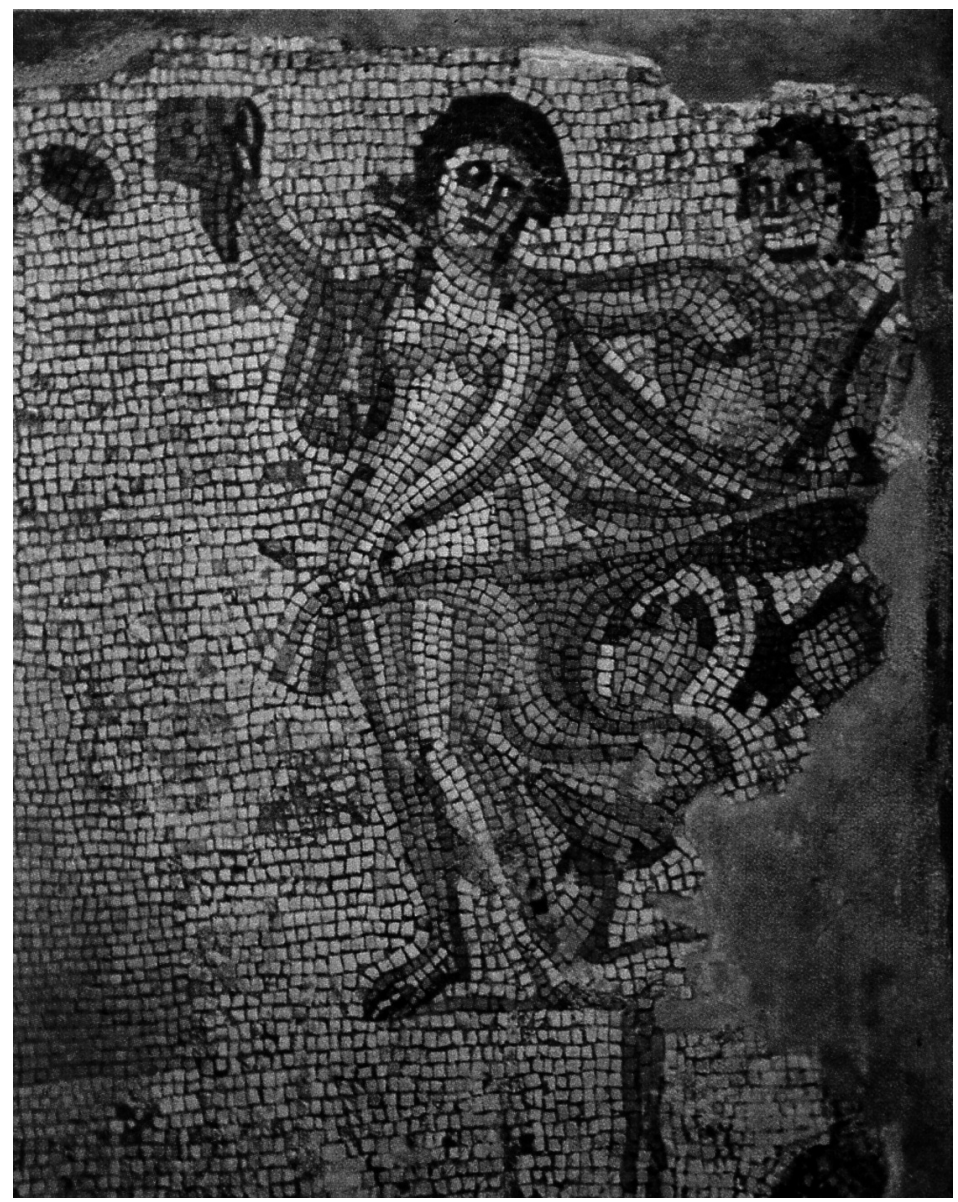

Fig. 11. Mosaico de Beyrouth (Líbano). Siglo IV.

Dentro de la iconografía del grupo se documentan otros ejemplares con distintas secuencias del tema de la aceptación amorosa que están integrados en el ciclo de los Amores de Zeus/Júpiter ${ }^{26}$. En el mosaico de Palermo del siglo III27 Antiope danza ante el sátiro, que aparece sentado y complaciente con objeto de conseguir su confianza (Fig. 12), mientras que en el pavimento tunecino de Ouled-

26 Solo vamos a señalar los mosaicos que cremos que tienen una identificación segura de los personajes como los que se insertan en los diferentes Amores de Zeus/Júpiter. En la villa de Fuente Alamo, Córdoba, apareció un sátiro y una ninfa, pero, según el contexto del pavimento, no se puede identificar con Zeus/Júpiter y Antiope, G. LOPEZ MONTEAGUDO ET ALII, El simbolismo del matrimonio en el mosaico de Fuente Alamo (Puente Genil, Córdoba) y otros mosaicos hispanos inéditos, Latomus XLVII/4, 1988, 786-795.

27 R. CAMERA-SCOVAZZO, Nuove proponte sul grande mosaico di Piazza della Vittoria a Palermo, Kokalos, 21, 1975, pp. 231-272. 
Agla, del siglo IV28, la doncella sujeta por la espalda al sátiro, que está a su lado, mirándole con dulzura (Fig. 13).

El mosaico de La Bodas de Cadmo y Harmonía procedente de la villa de La Malena, en Azuara (Zaragoza), fechado en los siglos IV-V, que decoraba una estancia de prestigio ${ }^{29}$, presenta cuatro cuadros con un interesante programa iconográfico de la última fase del mito o la consecuencia de la unión de Zeus/Júpiter y Antiope $^{30}$ (Fig. 14), descrita por las fuentes literarias: Júpiter, oculto bajo la apariencia de un sátiro engendró en la hermosa hija de Niceo (Antíope) dos gemelos...(Ovidio Met. VI. 110-111),

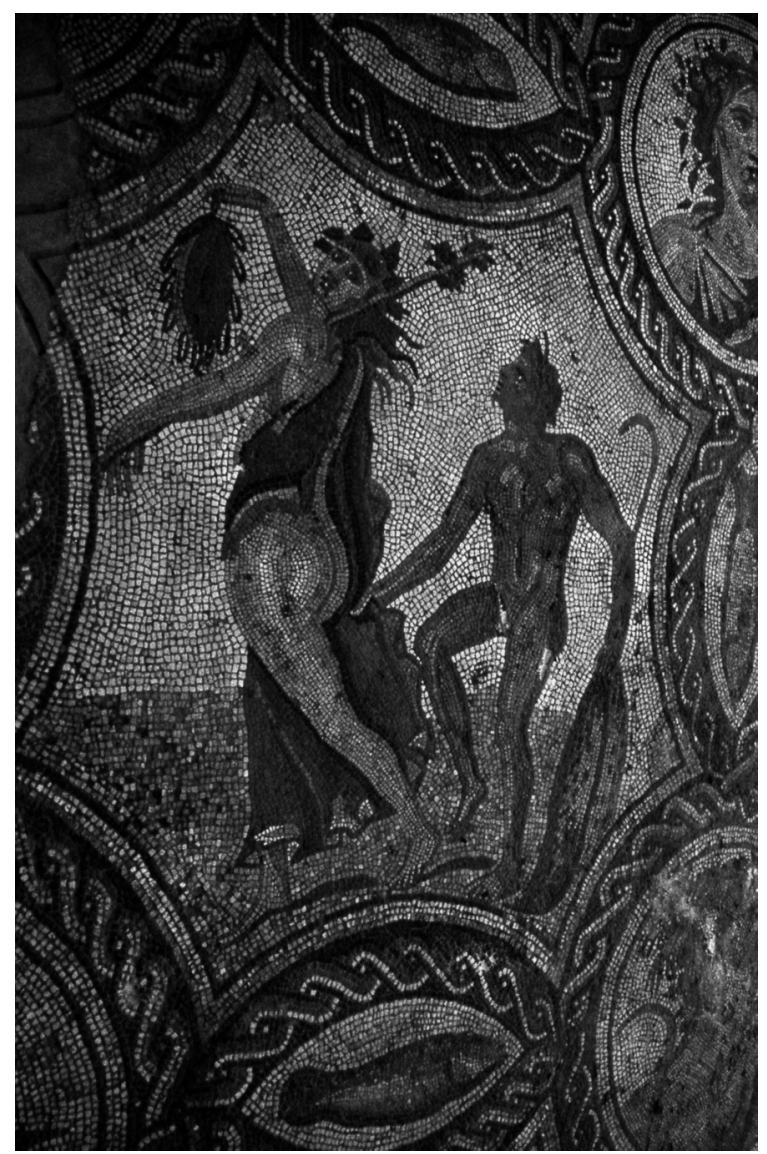

Fig. 12. Mosaico de Palermo (Italia). Siglo III.

${ }^{28}$ LIMC I, Antiope I, no 3b. En este mosaico se han representado a Europa y el toro, Dánae recibiendo la lluvia de oro, Ganímedes dando de beber a Zeus/Júpiter, Leda y el cisne.

29 J.I. ROYO ET ALII, Excavaciones en la Malena (Azuara, Zaragoza). 3a campaña 1988, Arqueología Aragonesa, 1988-89, 1991, p. 211-212,

30 D. FERNÁNDEZ-GALIANO, Cadmo y Harmonia. Imagen, mito y arqueología, Journal of Roman Archaeology,5, 1992, p. 162-172. 


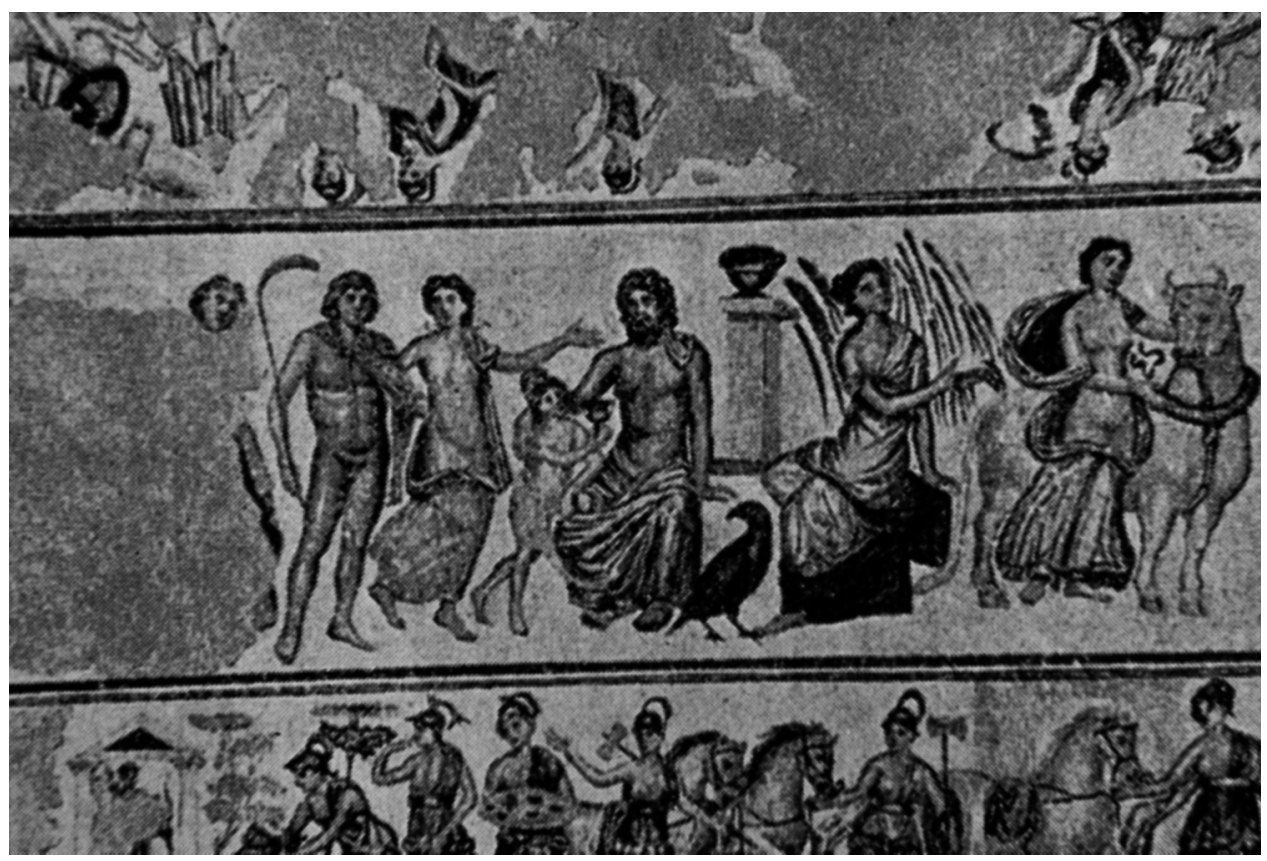

Fig. 13. Mosaico de Ouled-Agla (Túnez). Siglo IV.

En el primer cuadro se han figurado dos personajes, un hombre y una mujer tocada con un velo, de difícil identificación (Fig. 15). En el segundo aparecen, en la parte de abajo limitando el espacio de la llanura de Tebas, las alegorías de la fuente Dirce y del río Ismeno, y arriba Antiope ya liberada de las cadenas que aún cuelgan de sus muñecas, que huye nadandode la ciudad (Fig. 16). En otro cuadro aparece Antiope despidiendo a sus hijos, Anfión y Zethos, que van a vengarla (Fig. 17). Por último está representada la victoria final de Antiope, donde es coronada y honrada por sus hijos, formando ese grupo de divinidades preolímpicas compuesto por una madre y sus dos hijos ${ }^{31}$ (Fig. 18).

En conclusión, los ejemplares musivos con la representación de Antiope y el sátiro no son muy numerosos en comparación con las de otros personajes de los

31 El mito representado en este gran mosaico con el cautiverio, la liberación y la victoria final de Antiope introduce, entre las dos últimas secuencias, el episodio de Dirce, que gozó de un gran éxito en el arte griego y romano a partir del grupo iconográfico del famoso Toro Farnesio, del siglo II a. C., que se conserva en el Museo de Nápoles. El suplicio de Dirce se documenta igualmente en algunos mosaicos de Pompeya, Aquicum, Adana y Pola, Sagunto, Écija cf. LIMC III, « Dirke» y G. LOPEZ MONTEAGUDO, Los mosaicos romanos de Écija (Sevilla). Particularidades iconográficas y estilísticas, VIllème Colloque Internationale de la Mosaïque Antique (Lausanne 1997), vol. II, 2001, 131-132. 


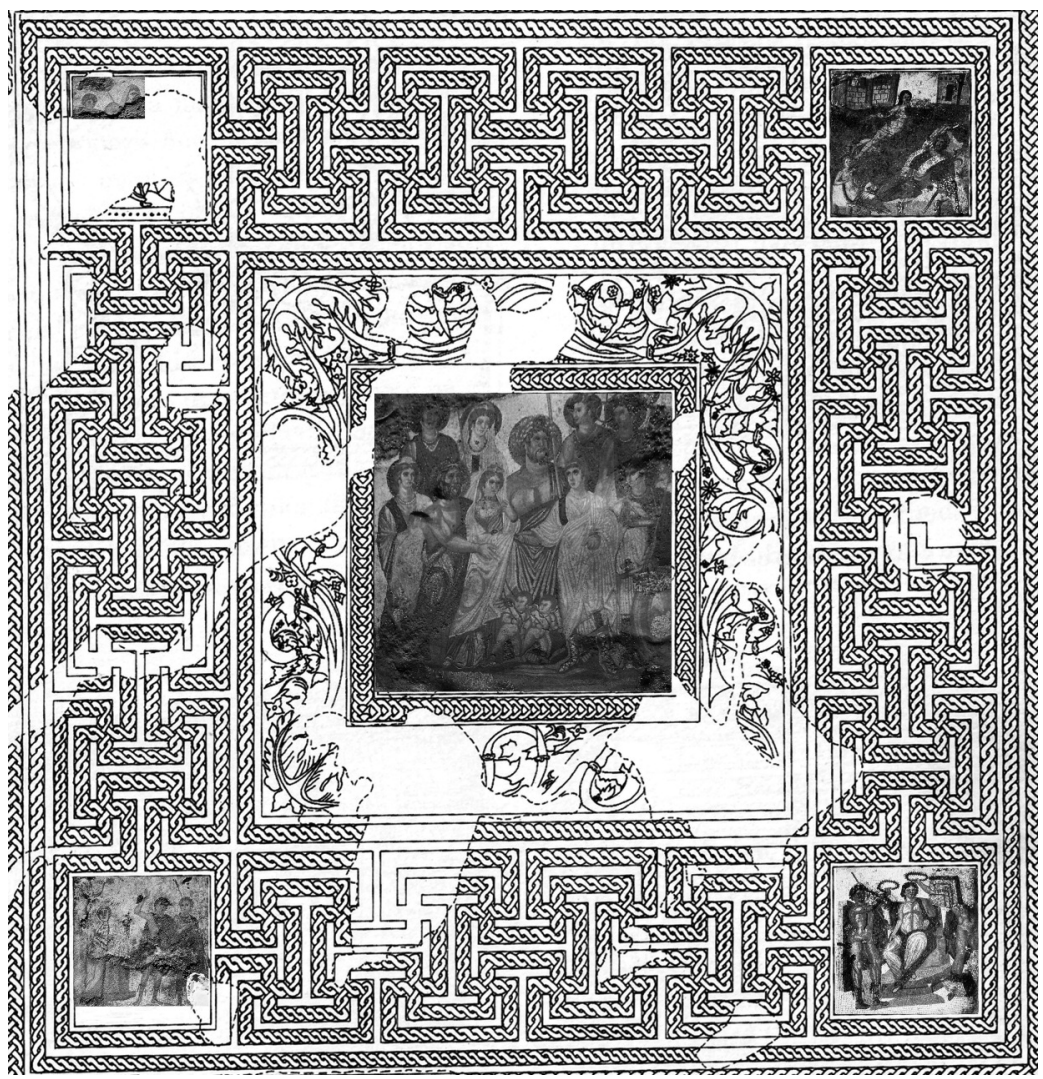

Fig. 14. Mosaico de Azuara, Zaragoza (España). Siglo IV-V.

Amores de Júpiter, como Europa y el toro ${ }^{32}$, Leda y el cisne ${ }^{33}$ o Ganímedes ${ }^{34}$. Dentro del repertorio del mito que narran las fuentes literarias, se aprecian tres grupos muy peculiares: primero el momento de la sorpresa o acoso, después el de la seducción y aceptación a través o no de la danza y un tercer grupo el de la consecuencia de la unión. Se utiliza una iconografía propia de las ménades/bacantes/nin-

32 G. LÓPEZ MONTEAGUDO y M.P. SAN NICOLÁS PEDRAZ, La iconografía del Rapto de Europa en el Mediterráneo occidental. A proposito de una lucerna del Museo de Sassari, $L$ Africa Romana VIII, 1991, 1005-1018: IDEM, op. cit. nota 383-438; IDEM, Astarté-Europa en la Península Ibérica. Un ejemplo de interpretatio romana, Homenaje M. Fernández Miranda, Complutum, Extra 6, 1996, 451-470.

${ }^{33}$ M.P. SAN NICOLÁS PEDRAZ, op. cit. en nota 6, 347-387; IDEM., op. cit. en nota 6.

34 L. FOUCHER, L enlévement de Ganymède figuré sur les mosaïques, Antiquités Africaines 14, 1979, 155-168 ; M. P. SAN NICOLÁS PEDRAZ, Iconografía de los Amores de Zeus. Análisis de los mosaicos hispanorromanos, Boletín de la Asociación Española de Amigos de la Arqueología (Homenaje a $D^{o}$ Vicente Viñas y $D^{a}$ Rosario Lucas Pellicer), 44, p. 239-257. 


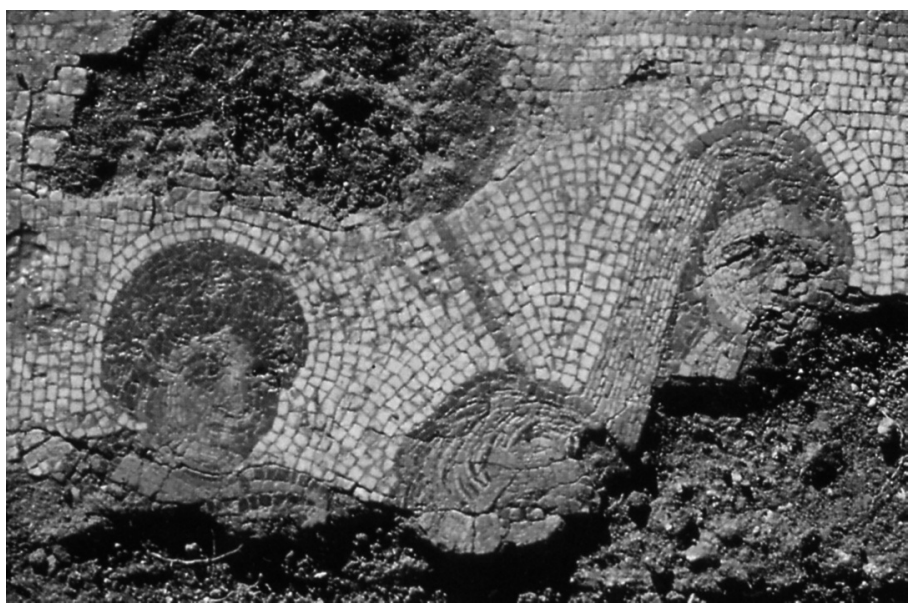

Fig. 15. Detalle del mosaico de Azuara, Zaragoza.

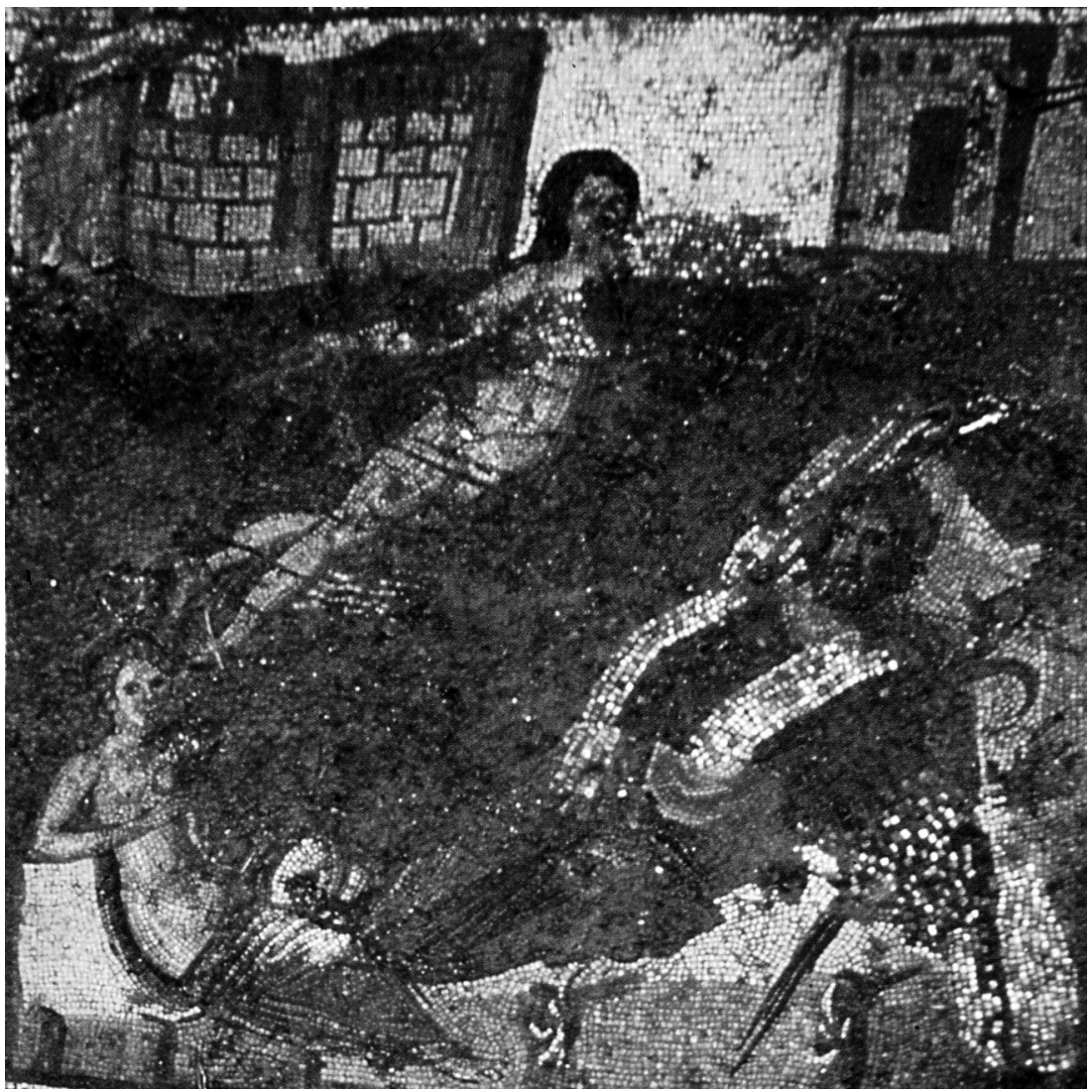

Fig. 16. Detalle del mosaico de Azuara, Zaragoza. 


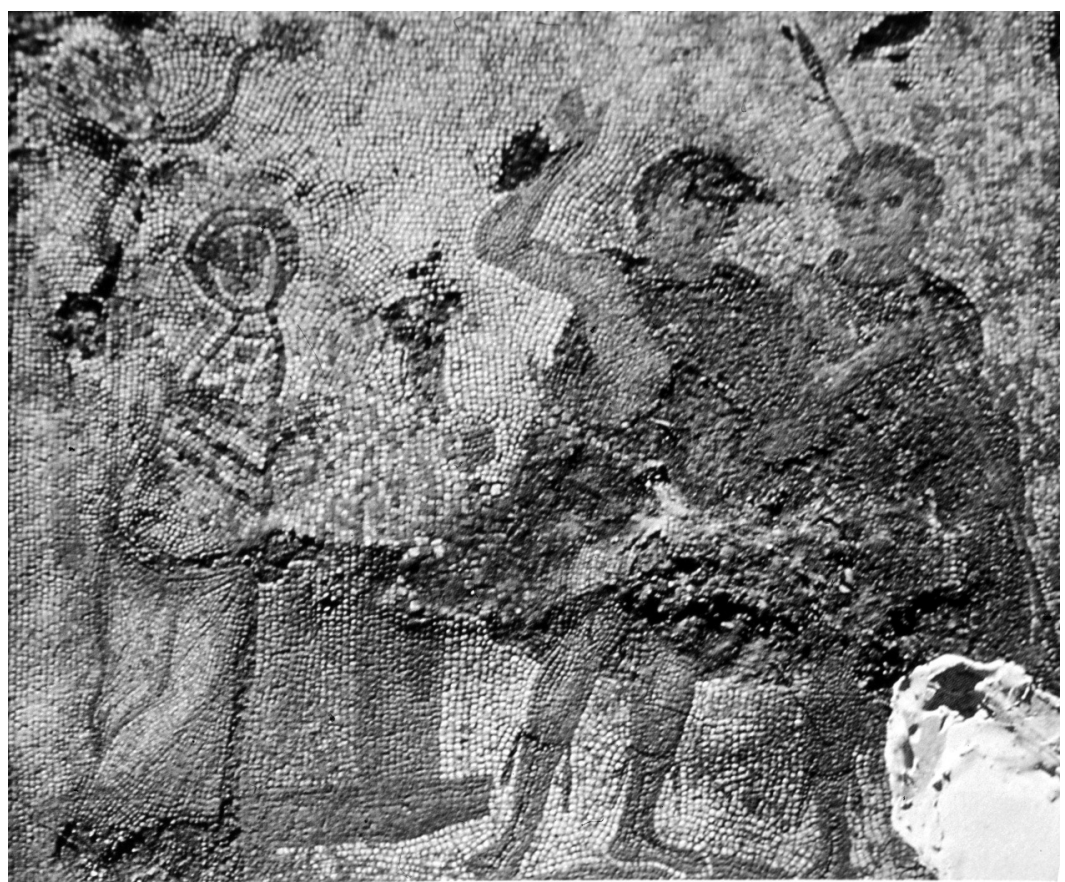

Fig. 17. Detalle del mosaico de Azuara, Zaragoza.

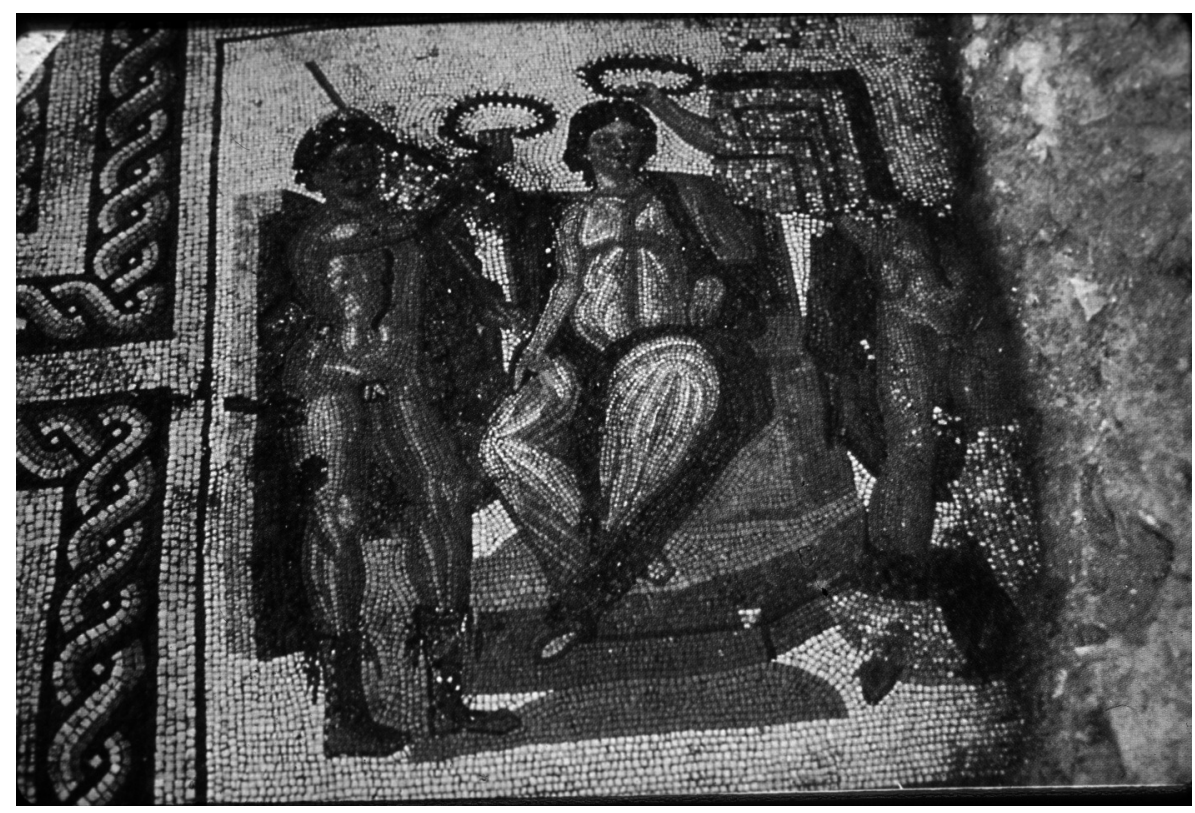

Fig. 18. Detalle del mosaico de Azuara, Zaragoza. 
fas del cortejo dionisiaco, y en ocasiones se emplea para la identificación de los personajes una inscripción, ya sea latina o griega. La cronología de estos ejemplares abarca desde el siglo II-VI.

Siguiendo la tesis de P. Vernant, estas escenas contienen un marcado simbolismo en relación con el matrimonio, que ocupa un lugar en el pensamiento y en la sociedad griega: antes de llegar al matrimonio los jóvenes han de cumplir unos ritos para obtener la condición humana, ella la loutroforia y él las pruebas guerreras. De esta forma, ambos pasan de ser parthenos y ephebos y acceden al matrimonio legítimo, porque todo intento de unión anterior no es más que una violación propia de sátiros. Por este motivo la iconografía de la pareja, Zeus/Júpiter y Antiope, sigue muy de cerca la de sátiro y ninfa, con acercamiento y rechazo, porque aceptar el matrimonio conlleva «ser domado» y alcanzar así la condición humana libre ${ }^{35}$.

En todo caso, aunque el tema erótico fue uno de los preferidos del repertorio doméstico de tradición helenística no solo debemos verlo como una simple aventura amorosa-gozosa, propia de algunas habitaciones concretas como los cubicula, sino como una alegoría de la fertilidad dentro de un programa iconográfico, no siempre implícita en la musivaria romana por su carencia narrativa. En consecuencia, la presencia del tema constituye, en contextos domésticos, una expresión de felicidad y bienestar eternos para los domini de la casa y, al mismo tiempo, manifiestan su riqueza personal y su estatus político-social.

\section{CATÁLOGO}

1. CÓRDOBA (ESPAÑA). Fragmento de un mosaico policromo con los Amores de Zeus/Júpiter. En uno de los recuadros aparece un eros con carcaj a la espalda y el haz en la mano. Siglo III. FERNÁNDEZ GALIANO (1982), p. 17-27. SAN NICOLÁS (2006), pp. 239-257.

2. ITÁLICA (ESPAÑA). Mosaico policromo con los Amores de Zeus/Júpiter. En un octógono aparece el dios metamorfoseado en sátiro persiguiendo a Antiope que se encuentra de rodillas de espaldas al espectador. Siglo II. A. BLANCO FREIJEIRO (1978), p. 25-26, n. 1, láms. 1-7; M. DURAN PENEDO (2008a), p. 1313, nota 46, p. 1315; ID. (2008b), p. 14, nota 68.

3. EL DJEM (TÚNEZ). Mosaico policromo. El sátiro persigue a la doncella y ella le rechaza con la mano. Principios del siglo III. L. FOUCHER, (1962), p. 15-25, láms. XV-XX; C. DULIERE y H. SLIM (1996), vol. III, p. 27, láms. XIV, LXV,7A.

4. TIMGAD (TÚNEZ) Mosaico policromo hallado en el caldarium de las Termas de los Philadelphi. El sátiro sujeta por detrás a Antiope que intenta huir de él. Principios del siglo III

35 J.-P. VERNANT, Le mariage, PP, 1973, 51-79 (= Mythe et societé en Grèce ancienne, Paris 1974, 57-81; H. HOFFMANN, Sexual and Asexual Pursuit, Royal Anthropological Institut Occasional Paper XXXIV, 1977, 3-4; C. SOURVINOU-INWOOD, A Series of Erotic Pursuits: Images and Meaning, JRS CVII, 1987, 131 ss.; G. LOPEZ MONTEAGUDO ET ALII, El simbolismo del matrimonio en el mosaico de Fuente Álamo (Puente Genil, Córdoba) y otros mosaicos hispanos inéditos, Latomus XLVII/4, 1988, 786795. 
S. GERMAIN (1969), p. 77-79, no 96, láms. XXXIII -XXXIV; K.M.D. DUNBABIN (1978), p. 275, n. 9

5. ANTAKYA (TURQUIA). Mosaico policromo. Casa del barco de Psique. El sátiro sujeta a la doncella que intenta levantarse del suelo. Siglo VI. D. LEVI (1947), p. 182-183, lám. C; LIMC III, Daphne, ํㅡ 22.

6. DEVYA (BULGARIA) Mosaico policromo hallado en el cubiculum-vestidor de la Casa de Antiope. En uno de los pentágonos aparecen el sátiro y Antiope de pie, tocados con coronas vegetales y desnudos, identificados con sus nombres en griego (CATIPOC/ANTIOPH). Siglo IV. A. MINCHEV (2002), p. 250-251, lám. 7; LIMC Antiope I, Suppl. 2009, p. 68.

7. ZEUGMA (TURQUIA) Mosaico policromo hallado en el cubiculum $\mathrm{P} 23$ de la Casa de Poseidón. Sátiro y Antipe bailando e identificados con su nombres en griego: ANTIO(P)H/CATYPOC. Finales del siglo II-mediados del III. M. ÖNAL (2002), p. 42-43; J.P. DARMON (2005), p. 1285-1286, lám. 6.

8. MÁLAGA (ESPAÑA). Mosaico policromo fragmentado de la hab. 1, cubiculum, de la villa de Torre de Benagalgón. El campo del mosaico, muy deteriorado, presenta dos calles laterales decoradas con peltas adosadas, alternativamente horizontales y verticales y un emblema central cuadrado en el que se inscriben un cuadrado sobre la punta y un círculo o medallón. En este medallón aparecen el sátiro y Antiope bailando e identificados con sus nombres en latín (SATIR/ANTIOPA). Siglo III. P. RODRIGUEZ OLIVA (2006), p. 21-33; I. MAÑAS, S. VARGAS (2007), p. 315-338.; P. RODRIGUEZ OLIVA, J. BELTRÁN FORTES (2008a), p. 1280-1288; ID. (2008b), p. 230-232; M.P. M.P. SAN NICOLÁS PEDRAZ (en prensa).

9. ZEUGMA (TURQUIA) Mosaico policromo hallado en el cubiculum P 38 (A14) de la Casa de Poseidón. El emblema esta rodeado en dos de sus lados por un marco de rectángulos con diversas aves; en el centro el sátiro y Antipe bailando e identificados con su nombres en griego (CATYPOC/ANTIOPH). Finales del siglo II-medidos del III. J.P. DARMON (2005), p. 1291-1293, lám. 12.

10. BEYROUTH (LÍBANO) Mosaico policromo con los Amores de Zeus/Júpiter. Sátiro y Antiope bailando. Siglo IV M. CHEHAB (958-1959), p. 21-27 ; O. WATTEL-DE CROIZANT (2001), II, p. 265-275.

11. PALERMO (ITALIA) Mosaico policromo con los Amores de Zeus/Júpiter. Antiope bailando mientras que el sátiro le mira sentado. Siglo III. R. CAMERA-SCOVAZZO (1975), pp. 231-272.

12. OULED-AGLA (TÚNEZ) Mosaico policromo con los Amores de Zeus/Júpiter. Antiope sujeta por la espalda al sátiro. Siglo IV. LIMC I, Antiope I, no 3b.

13. AZUARA, ZARAGOZA (ESPAÑA) Mosaico policromo Presenta cuatro cuadros con la consecuencia de la unión de Zeus/Júpiter y Antiope: un hombre y una mujer tocada con un velo; las alegorías de la fuente Dirce y del río Ismeno, Antiope ya liberada; Antiope despidiendo a sus hijos, Anfión y Zethos; Antiope coronada por sus hijos. Siglo IV-V. J.I. ROYO ET ALII (1991), p. 211-112: D. FERNÁNDEZ-GALIANO (1992), p. 162-172.

\section{BIBLIOGRAFÍA DEL CATÁLOGO}

BLANCO FREIJEIRO, A. (1978): Mosaicos romanos de Itálica, Corpus de Mosaicos romanos de España III, Madrid

CAMERA-SCOVAZZO, R (1975): Nuove proponte sul grande mosaico di Piazza della Vittoria a Palermo, Kokalos, 21, pp. 231-272.

CHEHAB, M. (1958-1959) : Mosaïque du Liban, BullMusBeyrouth, 14-15, p. 21-27.

DARMON, J.P. (2005) : Le programme idéologique de la maison de la Téleté dionysiaque, dite de Poseidón á Zeugma (Belkiis, Turquie), Actes du IX ème. Colloque International de la Mosaïque antique et médiévale, t 2 Roma pp. 1279-1300. 
DULIERE C. y SLIM, H (1996) : Thysdrus El Jem, en M. Alexander y M. Ennaifer, Corpus des Mosaïques de Tunisie, Túnez.

DURAN PENEDO, M. (2008a): Dirce y Antiope: dos imágenes de valores contrapuestos del ciclo tebano, L Africa Romana XVII, pp. 1299-1322.

ID. (2008b): Las preferencias iconográficas de los clientes refinados hispano-romanos, al encargar los mosaicos de sus viviendas, Monte Catano 9, pp. 99-118.

DUNBABIN, K.M.D. (1978): The Mosaics of Roman North Africa. Studies in Iconography and Patronage, Oxford.

FERNÁNDEZ-GALIANOD. (1992): Cadmo y Harmonia. Imagen, mito y arqueología, Journal of Roman Archaeology, 5, pp. 162-172.

FOUCHER, L. (1962) : Découvertes archéologiques à Thysdrus en 1960, Tunisie.

GERMAIN, S. (1969) : Les mosaïques de Timgad, Paris.

LEVI, D. (1947): Antioch Mosaic Pavements, Princeton.

LIMC= Lexicon Icononographicum Mythologiae Classicae

MAÑAS, I., VARGAS, S. (2007): Nuevos mosaicos hallados en Málaga: las villas de la Estación y de la Torre de Benagalbón, Mainake 29, pp. 315-338.

MINCHEV, A. (2002) : The Roman and Late Roman City, Conference veliki Turnovo (2000).

ÖNAL, M. (2002): Mosaics of Zeugma, Estambul 2002.

RODRIGUEZ OLIVA, P. (2006): Nuevos mosaicos romanos de la provincia de Málaga, Anuario de la Real Academia de Bellas Artes de San Telmo 6, pp. 21-33;

RODRIGUEZ OLIVA, P., BELTRÁN FORTES, J. (2008a): Villae romanas de la costa malacitana frontera al África. Las villae de Torrox-costa y de la Torre de Benagalgón, $L$ Africa romana XVII (2006), Roma, pp. 1275-1288;

ID. (2008b): Arqueología de las villae romanas de la costa malacitana, Habis 39, pp. 230 232.

ROYO, J.I. ET ALII (1991): Excavaciones en la Malena (Azuara, Zaragoza). 3aㅡ campaña 1988, Arqueología Aragonesa, 1988-89.

SAN NICOLÁS PEDRAZ, M.P. (2006): “ Iconografía de los Amores de Zeus. Análisis de los mosaicos hispanos romanos», Boletín Informativo de la Asociación Española de los Amigos de Arqueología (Homenaje a V. Viñas y R. Lucas Pellicer) 21, vol. 44, pp. 239-257.

ID. (en prensa): On Mosaic from Málaga with the depiction of Zeus/Jupiter and Antiope, La Mosaïque Gréco-Romaine IX, Bursa, Turquía.

WATTEL-DE CROIZANT, O. (2001): Les « amours des dieux» sur les mosaïques du Mussée National de Beyrouth, Actes du VIIleme. Colloque International de la Mosaïque antique et médiévale, (Lausana 1997), II, p. 265-275. 